Canadian Social Work Review

Revue canadienne de service social

\title{
HUMAN RIGHTS QUESTIONED
}

\section{A Queer Perspective}

\section{Nick J. Mulé}

Volume 35, numéro 1, 2018

URI : https://id.erudit.org/iderudit/1051107ar

DOI : https://doi.org/10.7202/1051107ar

Aller au sommaire du numéro

Éditeur(s)

Canadian Association for Social Work Education / Association canadienne pour la formation en travail social (CASWE-ACFTS)

ISSN

2369-5757 (numérique)

Découvrir la revue

Citer cet article

Mulé, N. J. (2018). HUMAN RIGHTS QUESTIONED: A Queer Perspective.

Canadian Social Work Review / Revue canadienne de service social, 35(1),

141-148. https://doi.org/10.7202/1051107ar d'utilisation que vous pouvez consulter en ligne.

https://apropos.erudit.org/fr/usagers/politique-dutilisation/ 


\section{HUMAN RIGHTS QUESTIONED A Queer Perspective NickJ. Mulé}

WITH THE RISE OF POPULISM, we find ourselves in particularly troubling times. Many of the gains hard fought for that resulted in human rights legislation to recognize and protect some of the most vulnerable and disenfranchised groups are now being trampled on by veiled and sometimes not-so-veiled messages and actions by groups of people, who themselves feel disaffected. As threatening as the current circumstance can feel, it also provides us with an opportunity to take a more in-depth and nuanced look at human rights as a concept. What is it about human rights that have put some people on edge to the point of lashing out against those most in need of them? Have human rights fallen short in educating the public as to its role and contribution to society? Are human rights effectively addressing the multiple imbalances experienced in society (including the disaffected critical of human rights)?

The focus of this paper is from the perspective of a progressive queer lens regarding the human rights of lesbian, gay, bisexual, transsexual, transgender, 2-spirit, queer, questioning, and intersex (LGBTQI) people, based on a history of human rights abuses against people who identify as, or are perceived to be, LGBTQI (Adam, 1987; Smith, 1999; Warner, 2002). This focus and lens need not be limited to gender and sexual diversity but can be extended to anyone concerned about human rights. Intersectionality of social locations has always run through gender and sexually diverse people, and as such, the human rights issues raised herein are applicable to society in general.

In this paper the importance of human rights will be discussed while simultaneously looking at its limitations and the dialectical implications this has. The erosive position human rights are currently in will be examined from a socio-political perspective that captures those who promote human rights and those who question them. Canada likes to present itself as being on a solid ground of human rights legislation,

Nick J. Mule is associate professor in the School of Social Work at York University and chair of the CASWE-ACFTS Queer Caucus.

Canadian Social Work Review, Volume 35, Number 1 (2018) / Revue canadienne de service social, volume 35 , numéro 1 (2018) 
but there is no denying the numerous imbalances that continue to exist and the challenges they create not only for those directly affected, but for Canadian society and the very notion that human rights are a tool of recognition and protection. Such imbalances and the challenges they pose will be decontextualized. I propose a more liberating response, one that albeit includes human rights but is not constrained by its limitations.

\section{Importance and Limitations of Human Rights}

Human rights and advocacy hold an important place in social work ethos as outlined by various Social Work Codes of Ethics and Principles of Practice (IASSW, n.d.; IFSW, 2012a, 2012b; CASW, 2005). Hence, social work has a history of social reform advocating social justice for the marginalized, disenfranchised and oppressed (Hutchinson Crocker, 1992). This now includes sexual orientation and gender identity and expression (IFSW, 2012). In Canada, the battle to get LGBTQIs included in formal human rights legislation has happened incrementally over time and is an ongoing initiative of the LGBTQI movement (Mulé, Forthcoming). For example, human rights recognition of LGBTQIs was initially advocated for and achieved by the movement for enumerated characteristic of sexual orientation (Warner, 2002). It has only been in the last number of years that provinces and territories, and eventually the federal government, included gender identity (and expression) in human rights legislation (Canadian Bar Association, 2016; Equaldex, 2017). Yet, recognition still eludes these populations, such as the Employment Equity Act and the omission of intersex people in formal legislative human rights.

Beyond incrementalism, a problem that underscores the concept of human rights is the premise of equality over equity. Too often human rights are fought for and designed to achieve equality in the eyes of the law. This in turn creates a limitation in formal human rights by constructing a form of legal justice that falls short of substantive material human rights, the latter of which, is only achievable via social justice. Formal human rights legislation, achieved through the conservatizing legal justice process, sets equality measures based on the status quo, which inevitably tends to be white, middle class, heterosexual, and cisgendered. For many who fall outside this normative realm (including many LGBTQIs), legal justice is out of reach. It is in the broader scope of social justice that those marginalized by human rights hope to be taken up.

\section{Discontent among the Populace}

If an underscoring tenet of human rights is to be based on equality, has this been achieved? Groups who have traditionally sought human rights recognition and protections (i.e. characteristics based on race, ethnicity, gender, gender identity/expression, age, accessibility, sexual orientation, 
class, creed, among others) have had to be vigilant due to ongoing human rights abuses or lack of implementation. Groups who do not necessarily fall into any of the traditionally-based recognized and protected human rights categories are feeling excluded and lacking a sense of the role human rights play in the reparation and equalization of a system that is innately oppressive to those who fall outside the majority or lack power. The LGBTQ movement from its earliest days as a liberationist front, learned from the Black liberation and women's liberation movements that came before, the importance of consciousness raising (Jay \& Young, 1972). This calls for a better understanding of human rights along with a continued commitment to decontextualize and reformulate them to reflect the ongoing shifting needs of the populace. The public in turn then needs to be educated about human rights, in its shape shifting form, to understand how this concept is to serve all in our respective social locations.

\section{Challenges of Imbalance}

On the surface it may appear that Canada is a very progressive country regarding human rights in general and LGBTQ populations in particular, especially in comparison to many other countries throughout the world. What is not to be forgotten is that these rights were a result of long, hard battles on the part of LGBTQ activists following years of heterosexist and homophobic abuse and oppression (Smith, 1999; Warner, 2002) that is still far from being eradicated (McCaskell, 2016). Also, rights acquisitions for LGBTQs have been incremental, initially based on sexual orientation, eventually extending to relationship recognition, parenting, adoption, and marriage (Equaldex, 2017; My Big Gay Family, 2015). Only recently has gender identity and expression become an enumerated characteristic in human rights legislation (Kirkness \& MacMillan, 2017). Yet, those with variant sex characteristics, referred to as intersex, continue to be absent in formal human rights protections (Dreger, n.d.). Hence, the varied groups that are captured under the growing category of gender and sexually diverse populations have, over time, experienced varying degrees of human rights recognition and protection, if at all, creating imbalances within the LGBTQI communities along the way.

Returning to equality being at the premise of human rights is also problematic to the point of inadvertently creating inequities down the line. When examining human rights legislation for LGBTQs in Canada it has inevitably been pursued via an equality agenda by equality-seeking LGBT groups. It is not surprising that the human rights LGBTQs have attained have been along the lines of traditional heterosexual standards (think marriage, reproduction, and adoption within a family unit led by a couple). By contrast, equity-seeking queer groups who tend to be more critical, radical, and progressive in their agenda are less interested in 
replicating heterosexual and cisgender norms than creating recognition and protection for a lifestyle that is not restricted by heteronormativity and cisnormativity (Mulé, 2015).

Importantly, it is essential we not lose sight of the impact intersecting social locations have on our existence. The social and power imbalances within the LGBTQ communities are quite pronounced for those who are female identified, racialized, impoverished and/or facing barriers to accessibility. Groups such as Black Lives Matter have brought these issues to the fore, disrupting not only mainstream society but LGBTQ communities themselves from continuing to think that human rights are evenly distributed (Black Lives Matter, 2013). The power imbalances within minority communities, such as LGBTQs, are not accounted for in human rights legislation. The most marginalized of minoritized communities find formal human rights inaccessible due to financial and emotional costs, not to mention human rights legislation being devoid of intersectional recognition. Once again, formal human rights legislation falls far short of being able to extend itself to on-the-ground, material, social justice issues that these individuals experience.

There are numerous examples of intersectional imbalances. HIV/ AIDS, which continues to significantly affect gay and bisexual men, has seen major progress in medical science shifting the disease from at one time being terminal, to a manageable chronic illness. The anti-retroviral medications now available in Canada have the ability to suppress the virus to being undetectable, resulting in significantly lowered levels of contagion (Challocombe, 2017). Yet, social policy has not caught up with the science. Criminalization of gay sex continues with regard to HIVpositive men regarding non-disclosure of their status (Fink, 2015), not to mention that most HIV-positive men charged with non-disclosure have been racialized. Also, there continues to be restrictions on men who engage in same-sex relations donating blood due to dated fears regarding HIV (Dryden, 2015). Two-Spirit Peoples advocated for inclusion in the Truth and Reconciliation Commission, only to be given a mere half page space in the 4,000-page report and they continue to be excluded from the Inquiry into Missing Indigenous Women and Girls (Robertson, 2017); Black members of the LGBTQ communities continue to be at risk of being carded, overly surveilled and targeted for crimes (NAACP, 2014). It is for these reasons they feel unsafe in the presence of the police, including at Pride events, a time of freedom and celebration, only to have the presence of uniformed law enforcement officials to remind Black LGBTQs of their vulnerabilities (Janus, 2017). Currently, one of the largest investigations is underway regarding a serial killer in Toronto's gay community, with questions being raised as to the slow response by the police and whether this is tied to the majority of the victims being racialized gay men (ASAAP, 2018). 
Further examples include lesbian, bisexual, and trans women who continue to be at risk of sexual harassment or assault regardless of their sexual orientation, gender identity or expression (Veldhuis, Drabble, Riggle, Wootton, \& Hughes 2018). As with all women they also continue to be on the lower end of the wage gap between the traditional binary sexes (Queer Ontario, 2017). Similarly, with the disabled, society has socially constructed an able-bodied and minded system that leaves LGBTQ disabled people with numerous barriers and limitations to live their lives freely (Kattari, 2015). The very oppressions imposed on LGBTQ people result in many unable to live to their full potential, impoverishing them in the process. Poverty is little understood in the LGBTQ communities but is prevalent (DeFillippis, 2016). Additionally, intersex members of the LGBTQ community are absent from human rights protections, allowing the medical system to decide for them in their infancy the sex they will be assigned based on their ambiguous genitalia (Meoded-Danon \& Yanay, 2016). This is an example of how systems can oppress, when in most cases other options are available including allowing the child the agency to make their own decisions when they have matured. The above examples of intersectional imbalances illustrate challenges to human rights.

\section{Towards a Liberating Approach}

As enticing as it is to entrench and cloak ourselves in the concept of human rights it may be more beneficial to step back from it and consider what has and has not been gained and how do we improve upon them to better address the challenging state of affairs we find ourselves in. In times of turmoil and instability, such as where we find ourselves these days, it can be helpful to return to some of the tenets of emancipatory work to remind ourselves of what needs to be focused on and how we can go about creating systems that are liberating rather than oppressive. An important tenet of gay liberationists at the dawn of the LGBTQ social movement was that seeking human rights was a means to an end, not an end in and of itself (Warner, 2002). They knew then, as we should not lose sight of today, that human rights claims are but one tool in the fight for recognition, but human rights alone will not achieve liberation (Mulé, 2016). Formal human rights legislation is ensconced in a legal justice framework, which in and of itself is confined within a conservatizing construct that prioritizes equality with assimilationist, status quo tendencies.

Human rights policies, although increasingly comprehensive of many social locations, are still designed monolithically, with little if any attention to intersectional existences and experiences. The emphasis on equality, limits the extent of human rights to the status quo, usually defined by the most powerful in society and whose life experiences are distant from the diverse, marginalized, and disenfranchised populations. Developing a liberating 
system calls upon us to take a critical look at human rights, who specifically they benefit, how they can be improved, inclusions and omissions therein, how accessible they are, and to be cognizant of their limitations. Even more importantly, gay liberationists called upon us to be imaginative, creative, and innovative in developing a system that goes beyond a restricted human rights legal justice focus to a broader emancipatory liberating system that frees people regardless of their sexual orientation, gender identity, and expression and/or sex characteristics (Mulé, 2016).

What a liberated society would ultimately look like is one that recognizes and values differences within all social locations at the ground level. It is at this level that social justice mobilizes and works its way up. A society committed to liberation would place equal value, if not greater, to social justice, recognizing the conservatizing limitations of legal justice. From a queer liberation perspective, it would mean a society in which all are free to embrace the sexual orientation, gender identity or expression of their choosing and accept people's sexual characteristics. From a broader liberation perspective, it would mean a society for which all social locations are accepted and celebrated without the need to tie the most mainstream of them to human rights protections.

\section{Conclusion}

In this Forum piece I have looked at both the importance and limitations of human rights as a concept. The current discontent in society in general was briefly looked at before engaging in an in-depth critical analysis of the challenges human rights are faced with due to numerous societal imbalances. I proffer a liberation approach that is more freeing than the inevitable limitations of human rights. An alternative way of looking at this is to consider that there could be good reasons for the erosion of human rights that we are currently witnessing, particularly if such human rights are not serving those they were meant to serve nor informing privileged others as to the importance of such rights. Additionally, working towards a society that liberates beyond the limitations of human rights is an initiative that social workers can contribute to along with the liberationists of all stripes towards a broader form of social justice.

\section{REFERENCES}

Adam, B. D. (1987). The rise of a gay and lesbian movement. Boston, MA: Twayne Publishers.

Alliance for South Asian AIDS Prevention (ASAAP). (2018). Call for action on missing South Asian and Middle Eastern men. ASAAP. Retrieved February 25, 2018 from http://asaap.ca/community-bulletin/

Black Lives Matter. (2013). Black Lives Matter: Celebrating 4 years. Retrieved February 25, 2018 from https://drive.google.com/file/ d/0B0pJEXffvS0uOHdJREJnZ2JJYTA/view 
Canadian Association of Social Workers, CASW. (2005). Code of Ethics. CASW: Retrieved February 25, 2018 from: https://www.casw-acts.ca/sites/caswacts.ca/files/attachements/casw_code_of_ethics.pdf

Canadian Bar Association. (2016). Letter: Inclusion of gender identity and gender expression in Nunavut Human Rights Act. Ottawa, ON. Retrieved from https:/ / www.cba.org/CMSPages/GetFile.aspx?guid=32ed971e-7e3a42e8-9190-10c231179c85

Challocombe, L. (2017). The epidemiology of HIV in gay men and other men who have sex with men. CATIE. Retrieved February 25, 2018 from http:/ / www.catie.ca/en/printpdf/fact-sheets/epidemiology/epidemiology-hivgay-men-and-other-men-who-have-sex-men

DeFillippis, J. N. (2016). "What about the rest of us?" An overview of LGBT poverty issues and a call to action. Journal of Progressive Human Services 27(3), p.143-174.

Dreger, A. (n.d.). Shifting the paradigm of intersex treatment. Retrieved July 25, 2007 from http:/ / www.intersexinitiative.org/pdf/dreger-compare.pdf

Dryden, O. H. (2015). “'A queer too far': Blackness, 'gay blood,' and transgressive possibilities." In O. H. Dryden \& S. Lenon (Eds.) Disrupting queer inclusion: Canadian homonationalisms and the politics of belonging (pp. 116 - 132). Vancouver, BC: UBC Press.

Equaldex. (2017). LGBT rights in Canada. Retrieved from http:/ / www.equaldex. $\mathrm{com} / \mathrm{region} /$ canada

Fink, M. (2015). "Don't be a stranger now: Queer exclusions, cecarceration and HIV/AIDS." In O. H. Dryden and S. Lenon (Eds.) Disrupting queer inclusion: Canadian homonationalisms and the politics of belonging (pp. 150 168). Vancouver, BC: UBC Press.

Hutchinson Crocker, R. (1992). Social work and social order: The settlement movement in two industrial cities, 1889-1930. Urbana: University of Illinois Press.

International Association of Schools of Social Work (IASSW). (n.d.) IASSW advocacy statement: Human rights and the open working group outcome document on sustainable development goals. IASSW: Retrieved February 25, 2018 from https://www.iassw-aiets.org/iassw-advocacystatement-human-rights/

International Federation of Social Workers (IFSW). (2012a). Sexual orientation and gender expression. Retrieved February 25, 2018 from http://ifsw. org/policies/sexual-orientation-and-gender-expression/

International Federation of Social Workers (IFSW). (2012b). Statement of ethical principles. Retrieved February 25, 2018 from: http://ifsw.org/ policies/statement-of-ethical-principles/

Janus, A. (2017, April 19). LGBT police officers group find it 'unacceptable' for city to fund pride. CBC News. Retrieved February 25, 2018 from http:/ / www.cbc.ca/news/canada/toronto/pride-funding-letter-1.4075745

Jay, K. \& Young, A. (Eds.) (1972). Out of the closets: Voices of gay liberation. New York, NY: Douglas Links. $150-168$

Kattari, S. K. (2015). "Getting it:" Identity and sexual communication for sexual and gender minorities with physical disabilities. Sexuality and Culture, 19(4), pp. $882-899$. 
Kirkness, J. \& MacMillan, S. (2017). Federal government adds "gender identity" and "gender expression" to Canadian Human Rights Act. Canadian Labour and Employment Law. Retrieved February 25, 2018 from https:/ / www.labourandemploymentlaw.com/2017/06/federal-government-addsgender-identity-and-gender-expression-to-canadian-human-rights-act/

McCaskell, T. (2016). Queer progress: From homophobia to homonationalism. Toronto, ON: Between the Lines.

Meoded-Danon, L. \& Yanay, N. (2016). Intersexuality: On secret bodies and secrecy. Studies in Gender E Sexuality, 17(1), 57-72.

Mulé, N. J. (2015). "The politicized queer, the informed social worker: Dis/reordering the social order" in B. J. O’Neill, T. A. Swan and N. J. Mulé (Eds.) LGBTQ people and social work: Intersectional perspectives (pp. 17-35). Toronto, ON: Canadian Scholars' Press.

Mulé, N. J. (2016). "Broadening theoretical horizons: Liberating queer in social work". In S. Hillock and N. J. Mulé (Eds.) Queering social work education (pp. 56-78). Vancouver, BC: UBC Press.

Mulé, N. J. (Forthcoming). "Sexual and gender diversity." In R. Harding, D. Jeyapal \& C. Walmsley (Eds.) Canadian social policy for Social Workers. Don Mills, ON: Oxford University Press.

My Big Gay Family. (2015). Lesbian access to IVF and IUI in Canada. Retrieved from http://www.mybiggayfamily.com/lesbian-access-to-ivf-andiui-in-canada/

National Association for the Advancement of Colored People (NAACP), (2014). Born suspect: stop-and-frisk abuses and the continued fight to end racial profiling in America. NAACP: Retrieved February 25, 2018 from: http:/ / action.naacp.org/page/-/Criminal\%20Justice/Born_Suspect_Report_ final_web.pdf

Queer Ontario (2017). Queer Ontario supports ending gender pay gap: Calls on provincial government to provide pay transparency on variety of genders. Queer Ontario. Retrieved February 25, 2018 from http://queerontario. org/page/2/

Robertson, D. C. (2017). Meet the two-spirit people fighting to be included in Canada's reconciliation process. Daily Xtra. Retrieved from https:// www.dailyxtra.com/meet-the-two-spirit-people-fighting-to-be-included-incanadas-reconciliation-process-77916

Smith, M. (1999). Lesbian and gay rights in Canada: Social movements and equality -seeking, 1971-1995. Toronto, ON: University of Toronto.

Veldhuis, C. B., Drabble, L., Riggle, E. D. B., Wootton, A. R., \& Hughes, T. L. (2018). "We won't go back into the closet now without one hell of a fight": Effects of the 2016 presidential election on sexual minority women's and gender minorities' stigma-related concerns. Sexuality Research $\mathcal{F}^{\circ}$ Social Policy, 15(1), 12-24.

Warner, T. (2002). Never going back: A history of queer activism in Canada. Toronto, ON: University of Toronto. 